\title{
PENDAMPINGAN BELAJAR SISWA DI LUAR KELAS DALAM MASA PANDEMI COVID-19 SEBAGAI IMPLEMENTASI MATAKULIAH MODEL PEMBELAJARAN INOVATIF
}

\author{
Dek Ngurah Laba Laksana'), Pelipus Wungo Kaka²), Wilfridus Muga3), \\ 4)Lidvina Wero \\ ${ }^{1,2,4)}$ Program Studi Pendidikan Guru Sekolah Dasar, ${ }^{3)}$ Program Studi Pendidikan Musik \\ 1,2,3,4)STKIP Citra Bakti \\ ${ }^{1)}$ laba.laksana@citrabakti.ac.id, 2)filipwungokaka@gmail.com, 3)faneza27@gmail.com, \\ 4)lidvina.wero@gmail.com
}

\begin{tabular}{|c|c|}
\hline Histori artikel & Abstrak \\
\hline $\begin{array}{l}\text { Received: } \\
5 \text { Oktober } 2020 \\
\\
\text { Accepted: } \\
5 \text { November } 2020 \\
\\
\text { Published: } \\
\text { 30 November } 2020\end{array}$ & $\begin{array}{l}\text { Mahasiswa dan STKIP Citra Bakti selaku lembaga pendidikan } \\
\text { tinggi mempunyai peran penting dalam mengembangkan konsep } \\
\text { belajar dengan berbagai situasi yang ada. Salah satu bentuk } \\
\text { implementasi dari matakuliah model-model pembelajaran inovatif } \\
\text { untuk mengakomodasi konsep merdeka belajar dan belajar dari } \\
\text { rumah. Untuk itu, akan dilakukan kegiatan pengabdian yang } \\
\text { bertujuan untuk memberikan pendampingan kepada siswa SD } \\
\text { melalui kegiatan belajar di luar kelas. Kegiatan ini dilakukan } \\
\text { dengan metode pendampingan belajar di luar kelas. } \\
\text { Pendampingan ini melibatkan } 24 \text { mahasiswa yang memprogram } \\
\text { matakuliah model model pembelajaran inovatif di SD. Pengabdian } \\
\text { dilakukan pada dua lokasi yaitu Kabupaten Ngada dan Kabupaten } \\
\text { Nagekeo. Hasil kegiatan pendampingan adalah (1) terjadi } \\
\text { peningkatan hasil belajar siswa setelah dilakukan pendampingan } \\
\text { belajar di luar kelas, dan (2) Respon positif diberikan oleh siswa, } \\
\text { guru, orang tua terhadap kegiatan pendampingan di luar kelas di } \\
\text { masa pandemi covid-19. }\end{array}$ \\
\hline
\end{tabular}

Kata-kata Kunci: belajar di luar kelas, model pembelajaran inovatif, belajar di masa pandemi Covid-19. 
Abstract. Students and Citra Bakti College as higher education institutions have an important role in developing the concept of learning with various existing situations. One form of implementation of the course on innovative learning models to accommodate the concept of independent learning and learning from home. For this reason, community service activities will be carried out aimed at providing assistance to elementary students through learning activities outside the classroom. This activity is carried out using the learning assistance method outside the classroom. This mentoring involved 24 students programming innovative learning model courses in elementary schools. The service was carried out in two locations, Ngada Regency and Nagekeo Regency. The results of the mentoring activities are (1) an increase in student learning outcomes after learning assistance outside the classroom, and (2) positive responses given by students, teachers, parents to mentoring activities outside the classroom during the Covid-19 pandemic.

Kata-kata Kunci: outside classroom learning, an innovative learning model, learning during the Covid19 pandemic.

\section{PENDAHULUAN}

Menteri Pendidikan dan Kebudayaan (Mendikbud) menerbitkan Surat Edaran Nomor 4 Tahun 2020 tentang Pelaksanaan Pendidikan Dalam Masa Darurat Coronavirus Disease (Covid-19). Dalam edaran tersebut terdapat beberapa konsep tentang belajar dari rumah. Konsep tersebut adalah pembelajaran dalam jaringan (daring)/jarak jauh dilaksanakan untuk memberikan pengalaman belajar yang bermakna bagi siswa, tanpa terbebani tuntutan menuntaskan seluruh capaian kurikulum untuk kenaikan kelas maupun kelulusan (Menteri Pendidikan dan Kebudayaan, 2020; Safrizal, Putra, Sofyan, dan Bimo, 2020).

Dalam edaran tersebut, dijelaskan bahwa pembelajaran daring/jarak jauh difokuskan pada peningkatan pemahaman siswa mengenai virus korona dan wabah Covid-19. Sementara aktivitas dan tugas pembelajaran dapat dilakukan secara bervariasi antar siswa, sesuai minat dan kondisi masing-masing, termasuk dalam hal kesenjangan akses/fasilitas belajar di rumah. Bukti atau produk aktivitas belajar diberi umpan balik yang bersifat kualitatif dan berguna dari guru, tanpa diharuskan memberi skor/nilai kuantitatif (Menteri Pendidikan dan Kebudayaan, 2020).

Dalam implementasinya banyak sekolah menerapkan belajar dari rumah, tetapi gurunya hanya memberikan pekerjaan saja kepada muridnya. Untuk itu, perlu juga guru dan orangtua ikut berinteraksi dan berkomunikasi membantu muridnya dalam mengerjakan tugasnya (Makarim, 2020; Menteri Pendidikan dan Kebudayaan, 2020).

Pendidikan saat ini mengalami masa krisis karena wabah Covid-19. Guru untuk pertama kali melaksanakan pembelajaran jarak jauh/pembelajaran daring. Untuk itu, diperlukan sinergitas antara siswa, orang tua, guru untuk melaksanakan pembelajaran dari rumah. Guru harus berinovasi untuk menjadikan pembelajaran tidak membosankan (Makarim, 2020).

Kondisi yang sala juga dialami di dunia pendidikan Provinsi NTT terkhusus di Kabupaten Ngada dan sekitarya (Manggarai Timur dan Nagekeo). Melalui instruksi Gubernur NTT yang disampaikan oleh Kepala Dinas Pendidikan dan Kebudayaan Provinsi NTT dikatakan bahwa anak-anak mulai dari jenjang Pendidikan Usia Dini sampai SMA, 
diharuskan belajar mandiri di rumah masing -masing. Anak-anak diwajibkan mengikuti proses belajar mengajar yang diberikan para guru secara online (www.gatra.com).

Pada dasarnya, belajar dapat dilakukan dalam berbagai lingkungan belajar. Belajar pada prinsipnya adalah perubahan perilaku yang terjadi pada struktur kognitif anak (Arend, 2008). Oleh karena itu, belajar dengan gaya belajar yang berbeda dapat dilakukan untuk menghasilkan pembelajaran yang efektif, efisien, dan mempunyai daya Tarik (Laksana, 2019a).

Menyikapi permasalahan tersebut, mahasiswa dan STKIP Citra Bakti selaku lembaga pendidikan tinggi mempunyai peran penting dalam mengembangkan konsep belajar dengan berbagai situasi yang ada. Salah satu bentuk implementasi dari matakuliah Model-model pembelajaran inovatif untuk mengakomodasi konsep merdeka belajar dan belajar dari rumah (Dasna, Laksana, dan Sudatha, 2015; Laksana, 2019a; Laksana, 2019b). Maka perlu dilakukan pendampingan belajar di luar kelas di masa pandemi ini. Dalam kegiatan pendampingan ini, siswa belajar berdasarkan desain pembelajaran berorientasi konsep belajar dari rumah sebagai bentuk implementasi merdeka belajar dimana didalamnya terdapat banyak aktivitas-aktivitas belajar, sehingga belajar menjadi lebih efektif, efisien dan dan menyenangkan (Laksana, Dinatha, dan Upayogi, 2020).

Sekolah-sekolah yang berada di daerah terdampak Covid-19 khususnya Kabupaten Ngada, Manggarai Timur dan Nagekeo belum dapat melaksanakan pembelajaran di dalam kelas. Pembelajaran di tiga kabupaten tersebut terganggu. Hasil wawancara dengan Koordinator Wilayah Kecamatan Golewa dan Golewa Barat menunjukkan bahawa pembelajaran hanya dilakukan melalui penugasan materi yang diberikan guru. Kegiatan lainnya adalah pendampingan belajar yang dilakukan oleh guru. Namun pendamingan ini belum maksimal karena jumlah anak yang cukup banyak. Hal ini berbading terbaik dengan keberadaan guru yang terbatas.

Kegiatan ini bertujuan untuk memberikan pendampingan kepada siswa SD melalui kegiatan belajar di luar kelas. Kegiatan ini dilakukan dengan metode pendampingan dan pelatihan. Pendampingan ini melibatkan 24 mahasiswa yang memprogram matakuliah model model pembelajaran inovatif di SD.

Kegiatan ini mempunyai 2 tujuan pokok, tujuan dari kegiatan pendampingan belajar di luar kelas di masa pandemi covid-19 adalah sebagai berikut. (1) Untuk meningkatkan hasil belajar siswa setelah dilakukan pendampingan belajar di luar kelas. (2) Untuk mengetahui respon siswa, guru, orang tua terhadap kegiatan pendampingan di luar kelas di masa pandemi covid-19 


\section{METODE PELAKSANAAN KEGIATAN}

Berdasarkan analisis situasi dan program yang direncanakan, karangka umum pemecahan masalah melalui kegiatan pengabdian ini adalah.

1) Ketua dan anggota pengusul merumuskan rancangan kegiatan yang disusun berdasarkan kebutuhan siswa.

2) Orangtua dan guru diajak berpartisipasi dengan melakukan keterlibatan langsung dalam memperoleh pengalaman dalam kegiatan belajar.

3) Orangtua dan guru diajak berdiskusi tentang pengalaman dan kendala yang dialami dalam mengikuti kegiatan yang ditawarkan.

Dalam realisasinya, langkah-langkah pemecahan masalah tersebut dapat dikemukakan sebagai berikut.

1) Tim pengusul berkoordinasi dengan kepala sekolah, guru kelas, dan orangtua siswa untuk mendiskusikan jadwal rencana kegiatan yang dirancang, mencakup program kegiatan, model pendampingan, waktu dan tempat pelaksanaan.

2) Peserta adalah siswa, orangtua, dan guru sekolah dasar beberapa SD di Kabupaten Ngada, Manggarai Timur, dan Nagekeo.

3) Waktu penyelenggaraan tiga kali seminggu selama bulan Mei-Juni 2020.

4) Tim penyusun program dari STKIP Citra Bakti menyiapkan program kegiatan sementara pihak guru dan orangtua membantu mendampingi kegiatan serta menyiapkan tempat belajar yang memadai.

Khalayak sasaran dalam kegiatan ini adalah siswa, orangtua, dan guru sekolah dasar beberapa SD di Kabupaten Ngada, Manggarai Timur, dan Nagekeo. Sejalan dengan cara pemecahan masalah yang ditempuh, maka sejumlah metode diterapkan dalam kegiatan ini (Laksana, Dinatha, dan Upayogi, 2020). Metode yang digunakan dalam kegiatan ini adalah metode pendampingan dan pelatihan. Deskripsi program dan indikator ketercapaian program disajikan dalam Tabel 1.

Tabel 1. Deskripsi Program dan Indikator Ketercapaian Program

\begin{tabular}{clll}
\hline No & \multicolumn{1}{c}{ Program } & \multicolumn{1}{c}{$\begin{array}{c}\text { Deskripsi pelaksanaan } \\
\text { kegiatan }\end{array}$} & $\begin{array}{c}\text { Indikator } \\
\text { Ketercapaian }\end{array}$ \\
\hline 1 & $\begin{array}{l}\text { Pendampingan } \\
\text { belajar di luar kelas }\end{array}$ & $\begin{array}{l}\text { Kegiatan ini dilakukan dengan } \\
\text { mendampingi siswa dalam } \\
\text { belajar dengan menggunakan } \\
\text { model pembelajaran inovatif }\end{array}$ & $\begin{array}{l}\text { Peningkatan hasil } \\
\text { belajar siswa }\end{array}$ \\
\hline 2 & $\begin{array}{l}\text { Respon siswa, } \\
\text { orangtua dan guru } \\
\text { dalam kegiatan } \\
\text { belajar di masa } \\
\text { pandemi covid-19 }\end{array}$ & $\begin{array}{l}\text { Melakukan wawancara terbuka } \\
\text { terkait pelaksanaan kegiatan } \\
\text { belajar di luar kelas di masa } \\
\text { pandemi covid-19 }\end{array}$ & $\begin{array}{l}\text { Respon yang } \\
\text { diberikan adalah } \\
\text { positif }\end{array}$ \\
\hline
\end{tabular}




\section{HASIL DAN PEMBAHASAN}

\section{Hasil Pendampingan}

Kegiatan pendampingan dilakukan pada 13 sekolah yang tersebar di dua kabupaten yaitu Ngada dan Nagekeo, NTT. Keempat sekolah tersebut antara lain: SDK Sambikoe dan SDI Tendakowe (Kabupaten Nagekeo); SDN Rutojawa, SDK Wolowio, SDK Waturoka, SDK Mangulewa, SDK Gurusina, SDI Welu, SDI Rutosoro, SDI Mulu, SDI Malanuza, SDI Golotawa, dan SDI Bobou (Kabupaten Ngada). Pendampingan dilaksanakan oleh mahasiswa STKIP Citra Bakti Program Studi PGSD Semester VI sekaligus mahasiswa yang mengambil matakuliah Model-model Pembelajaran Inovatif.
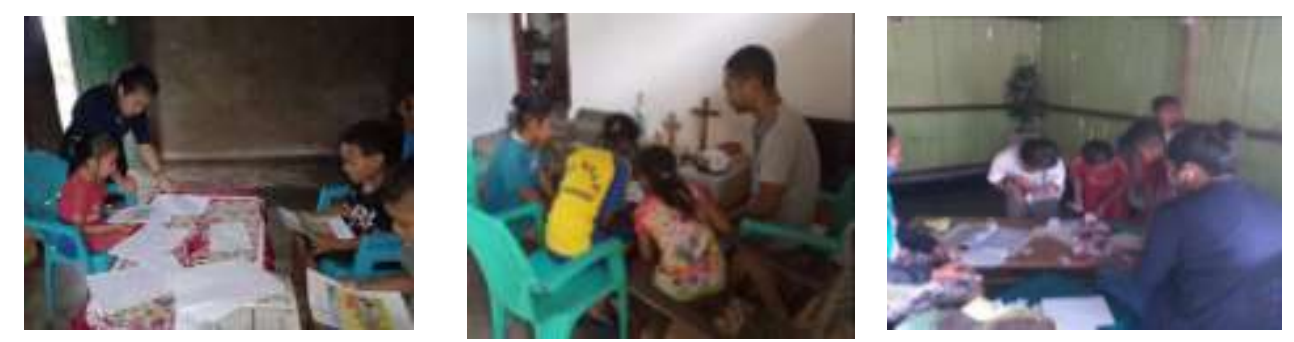

\section{Gambar 1. Aktivitas Pendampingan Anak Anak Belajar di Luar Sekolah}

Kegiatan dilaksanakan selama satu bulan, yaitu tanggal 15 Mei sampai 13 Juni 2020. Kegiatan ini menjalankan program pendampingan belajar yang dilaksanakan di luar kelas. Hasil kegiatan disajikan pada Tabel 2 berikut.

Tabel 2. Hasil Pendampingan Belajar

\begin{tabular}{|c|c|c|}
\hline No & $\begin{array}{c}\text { Nama } \\
\text { Kegiatan }\end{array}$ & Deskripsi Hasil \\
\hline 1 & Analisis Kebutuhan & $\begin{array}{l}\text { Kegiatan ini merupakan pendampingan belajar siswa di } \\
\text { rumah untuk siswa SDI Rutosoro. sebelum melakukan } \\
\text { proses pendampingan belajar, mahasiswa terlebih } \\
\text { dahulu melakukan } \\
\text { beberapa rangkaian kegiatan persiapan, dengan rincian } \\
\text { sebagai berikut: } \\
\text { 1. Mahasiswa mendatangi pihak sekolah (kepala sekolah } \\
\text { dan guru kelas) untuk menyampaikan maksud dan } \\
\text { tujuan pada tanggal } 15 \text { Mei } 2020 \text {. } \\
\text { 2. Mendatangi orang tua siswa untuk meminta ijin } \\
\text { melaksanakan kegiatan pendampingan tanggal } 15 \text { Mei } \\
\text { 2020. } \\
\text { 3. Mendata materi yang sudah diberikan oleh guru dan } \\
\text { materi yang harus dipelajari siswa secara mandiri di } \\
\text { rumah. } \\
\text { 1) Materi yang sudah dipelajari siswa: } \\
\text { a. Kelas I: materi dari tema } 1-5 \text {. } \\
\text { b. Kelas II : materi dari tema } 1-5 \text {. } \\
\text { c. Kelas III : materi dari tema } 1-5 \text {. } \\
\text { d. Kelas IV : materi dari tema } 1-6 \text {. } \\
\text { e. Kelas V : materi dari tema } 1-6 \text {. }\end{array}$ \\
\hline
\end{tabular}




\begin{tabular}{|c|c|c|}
\hline No & $\begin{array}{c}\text { Nama } \\
\text { Kegiatan }\end{array}$ & Deskripsi Hasil \\
\hline & & $\begin{array}{l}\text { 2) Materi yang harus siswa pelajari di rumah } \\
\text { a. Kelas I : materi tema } 6-8 \\
\text { b. Kelas II : materi tema } 6-8 \text {. } \\
\text { c. Kelas III : materi tema } 6-8 \text {. } \\
\text { d. Kelas IV : materi tema } 7-9 \text {. } \\
\text { e. Kelas V : materi tema } 7-9 .\end{array}$ \\
\hline 2 & Jadwal Belajar & $\begin{array}{l}\text { 1. Menyusun jadwal pendampingan belajar Jadwal } \\
\text { pendampingan belajar ini tidak teratur dan } \\
\text { disesuaikan dengan waktu luang } \\
\text { mahasiswa dan juga anak yang } \\
\text { akan didampingi. } \\
\text { 2. Menyusun materi pendampingan } \\
\text { 1) Pendampingan pada siswa kelas III tema } \\
7 \text { (Perkembangan Teknologi) dan sub tema } 1 \\
\text { Perkembangan Teknologi Subsidi Pangan. } \\
\text { Indikator : mengidentifikasi bentuk teknologi yang } \\
\text { digunakan dalam subsidi pangan. } \\
\text { 2) Pendampingan pada siswa kelas II tema } \\
8 \text { (Keselamatan di Rumah dan Perjalanan) sub } \\
\text { tema 3 Aturan Keselamatan di Jalan. } \\
\text { Indikator: mendeskripsikan aturan-aturan keselamatan } \\
\text { yang berlaku di jalan } \\
\text { 3) Pendampingan pada kelas IV tema } 8 \text { (Daerah } \\
\text { Tempat Tinggalku) sub tema Keunikan Tempat } \\
\text { Tinggalku. } \\
\text { Indikator: mendeskripsikan ciri khas tempat tinggal. }\end{array}$ \\
\hline 3 & Tes Awal & $\begin{array}{l}\text { Tes awal dilakukan secara lisan dalam bentuk pertanyaan } \\
\text { pengantar berkaitan dengan materi yang telah dipelajari } \\
\text { siswa sebelumnya dan tentang pemahaman awal materi } \\
\text { yang akn } \\
\text { dipelajari. }\end{array}$ \\
\hline 4 & Tes Akhir & $\begin{array}{l}\text { Tes akhir dilakukan dalam bentuk tes lisan dan tulis } \\
\text { berkaitan dengan pemahaman dan penguasaan materi } \\
\text { yang telah dipelajari bersama. }\end{array}$ \\
\hline 5 & $\begin{array}{l}\text { Respon Orang Tua } \\
\text { dan Guru }\end{array}$ & $\begin{array}{l}\text { 1. Respon orang tua } \\
\text { Secara garis besar orang tua sangat antusias dengan } \\
\text { kegiatan pendampingan yang dilakukan oleh mahasiswa } \\
\text { pada anak- anaknya. banyak hal yang menunjukan bentuk } \\
\text { dukungan orang tua terhadap kegiatan ini diantaranya } \\
\text { adalah mengingatkan anak mereka akan jadwal } \\
\text { bimbingan dan juga mempersiapkan anak mereka untuk } \\
\text { mengikuti bimbingan (kerapian berpakaian, perlengkapan } \\
\text { tulis, dan ketepatan waktu). }\end{array}$ \\
\hline
\end{tabular}

\section{Respon guru}

Kepala sekolah maupun para guru sdi rutosoro sangat mendukung dan mengapresiasi kegiatan bimbingan belajar yang dilakukan oleh mahasiswa pada beberapa siswa sdi rutosoro. Bentuk dukungan dan apresiasi yang dilakukan adalah dengan mengijinkan mahasiswa melakukan bimbingan belajar dan juga terlibat aktif dalam memberikan data materi-materi yang telah siswa pelajari di sekolah dan materi-materi yang belum dipelajari siswa 


\begin{tabular}{|c|c|c|}
\hline No & $\begin{array}{c}\text { Nama } \\
\text { Keqiatan }\end{array}$ & Deskripsi Hasil \\
\hline & & $\begin{array}{l}\text { dan harus dipelajari siswa secara mandiri di rumah. } \\
\text { Dukungan juga diberikan guru terhadap mahasiswa dalam } \\
\text { bentuk masukan dan ide-ide berkaitan dengan cara atau } \\
\text { teknik yang dapat digunakan dalam proses bimbingan. }\end{array}$ \\
\hline
\end{tabular}

\section{Pembahasan}

Kegiatan pendampingan ini adalah implementasi dari matakuliah model model pembelajaran inovatif, sekaligus menjawa tantangan belajar di masa pandemi. Dalam situasi pandemic ini, banyak sekolah menerapkan belajar dari rumah, namun gurunya hanya memberikan pekerjaan saja kepada muridnya. Untuk itu, STKIP Citra Bakti hadir sebagai pendamping belajar sekaligus mensosialisasikan peran orangtua untuk berinteraksi dan berkomunikasi membantu muridnya dalam mengerjakan tugasnya (Makarim, 2020; Menteri Pendidikan dan Kebudayaan, 2020).

Pada dasarnya, belajar dapat dilakukan dalam berbagai lingkungan belajar. Belajar pada prinsipnya adalah perubahan perilaku yang terjadi pada struktur kognitif anak (Arend, 2008). Oleh karena itu, belajar dengan gaya belajar yang berbeda dapat dilakukan untuk menghasilkan pembelajaran yang efektif, efisien, dan mempunyai daya tarik (Laksana, 2019a).

Menyikapi permasalahan tersebut, mahasiswa dan STKIP Citra Bakti selaku lembaga pendidikan tinggi mempunyai peran penting dalam mengembangkan konsep belajar dengan berbagai situasi yang ada. Salah satu bentuk implementasi dari matakuliah Model-model pembelajaran inovatif untuk mengakomodasi konsep merdeka belajar dan belajar dari rumah (Dasna, Laksana, dan Sudatha, 2015; Laksana, 2019a; Laksana, 2019b). Maka telah dilakukan pendampingan belajar di luar kelas di masa pandemi ini. Dalam kegiatan pendampingan ini, siswa belajar berdasarkan desain pembelajaran berorientasi konsep belajar dari rumah sebagai bentuk implementasi merdeka belajar dimana didalamnya terdapat banyak aktivitas-aktivitas belajar, sehingga belajar menjadi lebih efektif, efisien dan dan menyenangkan (Laksana, Dinatha, dan Upayogi, 2020).

\section{KESIMPULAN}

Dari hasil pendampingan belajar ini, terdapat dua kesimpulan, yaitu: (1) Terjadi peningkatan hasil belajar siswa setelah dilakukan pendampingan belajar di luar kelas. (2) Respon siswa, guru, orang tua terhadap kegiatan pendampingan di luar kelas di masa pandemi covid-19 adalah positif. 
Saran yang dapat penulis diberikan, antara lain: (1) Selama mengikuti kegiatan bimbingan belajar siswa di rumah banyak hal baru yang didapatkan oleh anak anak. Banyak hal yang cukup mudah dipelajari secara teori namun sulit untuk diterapkan secara langsung. Banyak pelajaran bermakna yang didapat diantaranya adalah bagaimana seorang guru harus mampu memahami berbagai karakteristik peserta didik dan memahami kondisi dan kebutuhan peserta didik. (2) Semoga kegiatan pendampingan ini ke depannya dapat berjalan dengan lebih baik dan menjalankan kerja sama yang lebih baik dari berbagai pihak (mahasiswa, peserta didik, orang tua dan pihak sekolah) agar hasil bimbingan lebih efektif.

\section{DAFTAR PUSTAKA}

Arends, R. I. (2008). Learning to teach. New York: McGraw Hill Companies.

Dasna, I.W., Laksana, D.N.L, Sudatha, I.G.W. (2015). Desain dan model pembelajaran inovatif dan interaktif. Tangerang: Universitas Terbuka.

Gatra.com. (2020). Pemprov NTT perpanjang libur sekolah hingga 21 april. Diterima pada 8 Mei 2020 melalui https://www.gatra.com/detail/news/473794/milenial/-pemprov-nttperpanjang-libur-sekolah-hingga-21-april

Instruksi Presiden No. 4 Tahun 2020 tentang penanganan dan pencegahan penyebaran virus corona coronavirus disease (Covid-19).

Laksana, D.N.L. (2019a). Kesulitan belajar anak dengan gaya belajar yang berbeda dalam menghadapi pembelajaran 4.0 serta strategi yang digunakan. Dalam D.N.L. Laksana (Ed), Pembelajaran di era big data dalam berbagai kondisi belajar (hal. 1-16). Serang: CV. AA. Rizky

Laksana, D.N.L. (2019b). Strategi pembelajaran: Kajian konseptual empiris di sekolah dasar. Surabaya: Kresna Bina Insan Prima

Laksana, D.N.L., Dinatha, N.M., \& Upayogi, I.N.T. (2020). Pendampingan pembelajaran tematik di luar kelas berbasis minat bakat di SDI Rutosoro. Jurnal Abdimas IImiah Citra Bakti, 1 (1), 1-10

Makarim, N. (2020). Pidato menteri pendidikan dan kebudayaan republik indonesia dalam peringatan hari pendidikan nasional tahun 2020. Jakarta: Kemendikbud

Menteri Pendidikan dan Kebudayaan. (2020). Surat edaran nomor 4 tahun 2020 tentang pelaksanaan pendidikan dalam masa darurat coronavirus disease (Covid-19). Jakarta: Kemendikbud

Safrizal, Z.A., Putra, D.I., Sofyan, S., \& Bimo. (2020). Pedoman umum menghadapi pandemi covid 19. Jakarta: Kementerian dalam Negeri. 